\title{
Portfolio Assessment Based Numbered Head Together Toward Students' Knowledge Competency of Mathematics
}

\author{
*Ni Luh Dian Purwatiningsih'1, I Gusti Agung Ayu Wulandari² \\ 1,2Program Studi Pendidikan Guru Sekolah Dasar, Universitas Pendidikan Ganesha, Singaraja, Indonesia
}

\author{
A R T I C L E I N F O \\ Article history: \\ 1 Mei 2020 Received in \\ revised form \\ 11 Juni 2020 \\ Accepted 10 Juli 2020 \\ Available online 25 Agustus \\ 2020

Kata Kunci:
NHT, penilaian portofolio,
matematika
Keywords:
NHT, portfolio
assessment, mathematics

\begin{abstract}
A B S T R A K
Rendahnya kompetensi pengetahuan matematika siswa disebabkan oleh kurang optimalnya penggunaan model pada saat pembelajaran sehingga siswa sulit memahami pembelajaran. Terbukti dari hasil observasi, nilai PTS Matematika siswa sebanyak 53 orang atau $21.73 \%$ sudah mencapai KKM sedangkan sebanyak 191 orang atau $78.27 \%$ belum mencapai KKM. Penelitian ini bertujuan untuk menganalisis pengaruh model NHT berbasis penilaian portfolio terhadap kompetensi pengetahuan matematika kelas $\mathrm{V}$ SD. Penelitian ini merupakan penelitian eksperimen semu dengan rancangan kelompok nonequivalent control group design. Populasi adalah seluruh kelas V SD yang terdiri dari 10 kelas sebanyak 244 siswa. Sampel ditentukan menggunakan teknik random sampling, sehingga terpilih 69 siswa. Metode pengumpulan data menggunakan tes objektif pilihan ganda, sehingga didapatkan data berupa nilai kompetensi pengetahuan
\end{abstract} matematika yang berbentuk data kuantitatif, kemudian dianalisis menggunakan analisis uji-t dengan rumus polled varians. Hasil analisis data diperoleh thitung $=4,351>$ tabel $=2,000 \quad(\alpha=0,05$ dan $\mathrm{dk}=67)$ maka $\mathrm{H}_{0}$ ditolak dan $\mathrm{H}_{\mathrm{a}}$ diterima yang artinya terdapat perbedaan yang signifikan antara kelompok eksperimen dan kelompok kontrol. Maka disimpulkan model NHT berbasis penilaian portfolio berpengaruh terhadap kompetensi pengetahuan matematika kelas V SD.

\section{A B S T R A C T}

The low competency of students' mathematical knowledge is caused by the lack of optimal models during learning so the students find it difficult to understand learning. It was proven by the results of observations, 53 students or $21.73 \%$ of Mathematics PTS scores had reached KKM while as many as 191 people or $78.27 \%$ had not yet reached the KKM. This study aimed at analyzing the effect of the NHT model based on portfolio assessment on the competency of the fifth-grade elementary school. This research was a quasi-experimental study with a non-equivalent control group design. The population was all grade V elementary schools consisting of 10 classes of 244 students. The sample was determined using a random sampling technique so selected the fifth grade (Elementary School) SD 1 Mengwi of 34 students as the experimental group and the fifth grade Elementary School Mengwi of 35 students as a control group. In the process of data collection, the test was chosen as a research instrument in the form of an ordinary multiple-choice objective test so the obtained data in the form of mathematical knowledge competency values in the form of quantitative data, then it was analyzed using uji-t analysis with the polled variance formula. The results of data analysis obtained tcount $=$ 4.351>ttable $=2,000(\alpha=0.05$ and $\mathrm{dk}=67)$ then $\mathrm{H}_{0}$ was rejected and Ha was accepted, which means that there are significant differences between the experimental and control groups. Based on these results, it can be concluded that the NHT model based on portfolio assessment influences the competency of mathematics knowledge in the fifth-grade elementary school. 


\section{Introduction}

Mathematics comes from the word manthanein which means learning. Whereas in Dutch mathematics comes from the word wiskunde which means exact science. Mathematics is a subject at the level of education from elementary to a tertiary level that can develop critical, creative, and active thinking (Hartono et al., 2015; Mariani, 2017) Mathematics is a discipline that deals with solving problems in everyday life. In fact, students consider Mathematics to be rigid and boring. This results in low competency of students' mathematical knowledge (N. Atiyah et al., 2018). The low competency of students' mathematical knowledge is proved by the results of the annual PISA study organized by the Organization for Economic Cooperation and Development (OECD). In 2018, Indonesia ranked 73 out of 79 countries with a score of 379 while the international average was 489 (OECD, 2018). Indonesia has quite a distance compared to the international average. PISA results in 2018 experienced a decline, namely down from rank 63 in 2015 with a score of 386 from the average international score of 490 (OECD, 2018). Indonesia is always in the top ten position from the bottom for Mathematics content. A similar study was also conducted by the Ministry of Education and Culture government through the Indonesia National Assessment Program in 2016 to explain the low mastery of Indonesian students' Mathematics lessons. Approximately 77.13\% of elementary school students throughout Indonesia have very low math competency, $20.58 \%$ is sufficient and only $2.29 \%$ are in good category (Kemendikbud, 2016). The results of the case study indicate that Indonesia is still low in Mathematics learning. Based on the results of observations and interviews, similar problems were also found, namely the low competency of mathematical knowledge in elementary schools. It is proven that the value of PTS Mathematics in the first semester of class 5 Elementary School Cluster VIII Mengwi from 244 students as many as 53 students or $21.73 \%$ had reached the KKM while as many as 191 students or $78.27 \%$ had not reached the KKM. Competency is a combination of individual knowledge, attitudes, and skills that are reflected through actions and thoughts (Yuliantari et al., 2016). In the 2013 curriculum, knowledge competencies are coded KI-3. Mathematical knowledge competencies are the change in students' behavior that reflect students' ability to master learning in terms of knowledge after experiencing the learning process. The low competency of knowledge is caused by various factors, namely the use of innovative learning models that still need to be varied and optimized because it can make it easier for teachers to convey information, foster interest in learning and a pleasant learning atmosphere. In addition, in Mathematics learning, students are less enthusiastic and active in learning, while in the 2013 curriculum students are required to be active during the learning process. Therefore, teachers must be able to package and design learning activities using innovative and varied learning models so that students are interested and feel happy in following the learning process (Atiyah et al., 2019; Hadiyanti et al., 2012). Based on these problems, it is necessary to have learning innovations that optimize student enthusiasm and activeness so that competencies can be increased by applying the Numbered Head Together (NHT) model.

The NHT model is group learning that involves 3-5 people to solve a problem and it is suitable to be applied in the learning process because it can actively involve all students, not just one or two persons (Atiyah et al., 2019; Fajar Kurniati, 2017). The NHT model demands cooperation between groups to cover up deficiencies in the group and try to solve problems together (Novitasari, 2016). In addition, the use of this model aims to provide opportunities for students to share ideas and consider the most appropriate answers. The NHT model is part of the structural cooperative learning model, which emphasizes special structures designed to influence student interaction patterns (Sudarwanto, 2018). The hallmark of the NHT model is that the teacher only appoints a student to represent the group without first telling who will represent the group. Therefore, this method ensures the involvement of all students and trains students' individual responsibility (Kurniasih \& Sani, 2015). So, it can be concluded that the NHT model is a group learning model consisting of 3-5 people and each group member is given a different head number, then all group members participate in solving a problem and make sure all group members understand the given problem. The advantage of the NHT model can make students ready and sincere in group discussions. It is because during the learning process the teacher randomly calls student numbers to work on the problems raised by the teacher. In addition, clever students will teach group members who do not understand so all group members understand the material being discussed. There are no students who dominate to deliver the results of the discussion because the teacher randomly calls the student's number (Paramita et al., 2016).

The syntax of the NHT model is divided into five phases, namely (1) numbering, the teacher divides students into groups of 3-5 people and assigns a different number to each group member; (2) 
asking questions, the teacher poses problems or gives student worksheets and this is done with the group; (3) thinking together in groups, students discuss problems given by the teacher; (4) answering a question, the teacher calls a random number to work on the results of the discussion; (5) the conclusion, the teacher and students conclude the learning (Fajar Kurniati, 2017). The advantage of the Numbered Head Together learning model, namely increasing student self-confidence, increasing student communication skills, more developed tolerance, deeper understanding of the material, and increasing student outcomes in learning, besides that the NHT model increases students' achievement, deeper students' understanding, curiosity becomes more developed, the sense of cooperation is more developed, the students are more motivated in mastering the material, the creation of a cheerful atmosphere in learning, the difference students' intelligence is reduced (Berlin \& Kurniasih, 2015; Priansa, 2017). Several relevant research results reinforce that the NHT model has a positive impact on learning success, including a study conducted by (Dwicahyani et al., 2019) state that social science competency are increased with the image media assisted NHT. (Adnyana et al., 2014) state that the NHT model can increase student activity and learning outcomes. (Putu et al., 2017) state that audio-visual media assisted NHT model affects the competency of students' social science knowledge. To measure learning achievement, existing types of assessments are used.

One type of assessment is a portfolio, a portfolio assessment is part of an authentic 2013 curriculum assessment that is suitable for learning. Portfolio assessment is an assessment about collecting evidence of work samples and select student works that are conducted within a certain period of time. The students' selected work is the best, memorable, and meaningful student work. The results of student works collection can be stored in a bundle or folder. Portfolios can be in the form of worksheets, test papers, homework books, assignments as evidence of student performance, then portfolio assessments are also used to monitor student abilities by filing students' work within a certain period (Marselina \& Kristiantari, 2019; Sumardi, 2017). The advantage of using portfolio assessment in learning is that students can describe their own learning and know the extent of students' abilities. In addition, the use of teacher's portfolio is used to find out the progress of students individually or in groups and motivate students during lessons (Kusuma et al., 2015). Through portfolio assessments, teachers can document and assess student work results so that they can monitor student progress from day to day and encourage students to reflect on their own learning. Thus, students can be motivated and improve their learning outcomes (Darsana et al., 2019). Previous researchers had also conducted relevant research on portfolio assessment to strengthen this research, including a study conducted by (Djonomiarjo, 2020) which states that the Portfolio based PBL model affects student Civics learning outcomes. Juniyanti et al. (2015) state that the application of portfolio assessment based scientific approach can improve students' competency in procedural knowledge. (Oktarini et al., 2014) state that portfolio assessment affects Civics learning outcomes. Thus, it can be said that portfolio assessment has a positive impact on the learning process.

Theoretically, the NHT model and portfolio assessment have a positive impact on learning success. With the collaboration of the NHT model with portfolio assessment, it will have an impact on the achievement of the learning objectives that have been programmed. It is based on the result of a study conducted by (Riani et al., 2014) which states that the effectiveness of the NHT model with portfolios is better than TGT, this is indicated by the results of the average value of learning outcomes in the NHT experimental group is 28.47. Referring to these relevant studies, the difference in conducted research relies in the learning material and the subjects. Based on this explanation, it is necessary to conduct a study to improve the competency of students' knowledge in mathematics as well as a concrete evidence to document the students' progress of learning outcomes over a certain period of time. Therefore, to find out how far the model and portfolio assessment can affect the competency of students' mathematical knowledge, a study was conducted with the aim of this study to analyze the significant effect of the implementation of the portfolio assessment based NHT on the competency of mathematics knowledge in the fifth grade elementary school Cluster VIII Mengwi. Theoretically, the NHT model and portfolio assessment contribute to the competency of mathematical knowledge but this theory needs to be proven scientifically through trials or experiments.

\section{Method}

This study was conducted in elementary schools located in Cluster VIII Mengwi. This study was a quasi-experimental study with a non-equivalent control group design. This design has a control group, but it cannot fully function to control external variables affecting the implementation of the experiment (Sugiyono, 2015). In this design, the posttest value regardless of the pretest value was the main concern because the purpose of this study was to determine the effect of not the increase in the competency of 
mathematical knowledge in the experimental group that was given treatment, while the control group was not given treatment. Giving pretest to both groups to measure group equivalence. The technique used for group equalization was the t-test. Furthermore, a post-test to obtain competency data on mathematical knowledge of the two groups.

In this study, the population was all the fifth-grade students at Elementary School Cluster VIII Mengwi in Academic Year 2019/2020 of 244 students. The sample members were determined by random sampling technique, in which the class was randomized so that each class had the same opportunity to become the research sample. In this study, the sample selection did not conduct individual randomization but class randomization only. It was because formed class was not able to be changed. The selected class as it was formed without the intervention from researcher and the absence of individual randomization, the possible effects of the students knowing that they were involved in the experiment can be reduced so that this study really illustrated the effect of the treatment. In this study, the sample were students of the fifth grade Elementary School Number 1 Mengwi with 34 students as an experimental group with treatment in the form of the portfolio assessment based NHT and the students of Elementary School Number 3 Mengwi with 35 students as a control group with treatment in the form of conventional learning. The independent variable of this study was the portfolio assessment based NHT model. Meanwhile, the dependent variable in this study was the competency of mathematical knowledge.

The collected data was the competency test of mathematic knowledge on the fifth grade Elementary School Cluster VIII Mengwi in academic year 2019/2020. The method used in data collection was the test method, namely the objective test (in the form of ordinary multiple choice) with a total of 35 items. This typical multiple-choice test includes 4 answer choices (a, b, c, or d). Each item was given a score of 1 if the answer was correct (the answer is adjusted to the answer key) and a score of 0 was for wrong answer. The scores for each answer were added up and the number became the score for the competency variable of mathematical knowledge, which ranged from 0-35. Score 0 was the lowest score and 35 was the highest score. Then, to get the competency score of mathematical knowledge, the raw score was divided by the maximum ideal score multiplied by 100 . The preparation of the test was based on Basic Competency (KD) and indicators that were based on with the material, namely the volume of space. The grid of mathematical knowledge competency test was presented in table 1 as follows.

Table 1. The Grid of Mathematics Knowledge Competency Test

\begin{tabular}{|c|c|}
\hline $\begin{array}{c}\text { Basic Competency } \\
\text { (KD) }\end{array}$ & Indicator \\
\hline $\begin{array}{l}\text { Describing and determining the } \\
\text { volume of a spatial shape using } \\
\text { volume units (such as cubes and } \\
\text { unit blocks) and the cube } \\
\text { relationship with the cube root }\end{array}$ & $\begin{array}{l}\text { 3.5.1 Analyzing the conversion of the building } \\
\text { volume unit } \\
\text { 3.5.2 Identifying the cube and block elements } \\
\text { 3.5.3 Identifying the volume formulas for cube and } \\
\text { blocks } \\
\text { 3.5.4 Calculating the volume of a cube using unit } \\
\text { cubes } \\
\text { 3.5.5 Calculating the volume of cube and block } \\
\text { 3.5.6 Calculating the cube of number and the cube root } \\
\text { 3.5.7 Analyzing the associated problem with cube } \\
\text { number and root } \\
\text { 3.5.8 Analyzing daily problems regarding the volume } \\
\text { of cube and blocks }\end{array}$ \\
\hline
\end{tabular}

Description:

$\mathrm{C} 1=$ Remember

$\mathrm{C} 2=$ Understand

C3 = Apply

$\mathrm{C} 4=$ Analyze

Descriptive statistics and inferential statistics were used to analyze the data. Descriptive statistics were used to describe the results of the study through a histogram, and the mean was converted to a five-scale PAP. Then, inferential statistics were used to test the proposed hypothesis using the t-test with the polled variance formula. However, before that, the prerequisite test was conducted first, namely the 
data normality test using Chi-Square test and the homogeneity test with the F-test (Fisher). To determine whether the obtained sample data was normal in distribution or not, it was necessary to test the normalization of the data distribution. Sample data that is normally distributed means that the data has a perfect and balanced distribution of the average score. This test can be tested using the Chi Square technique. The testing criteria are based on a significance level of $5 \%$, if $\mathrm{X}^{2}$ count $<\mathrm{X}^{2}$ table means that the data is normally distributed. The second prerequisite test that must be fulfilled is the variance homogeneity test. The homogeneity test of variance is conducted to ascertain differences in groups that are the cause of differences in hypothesis testing and it is not because of differences between groups. Therefore, the F-test is conducted with the provision that if $F_{\text {count }} \leq F_{\text {table, }}$ the data is homogeneous.

\section{Result and Discussion}

To obtain an overview of the mathematical knowledge competency, the data were analyzed using descriptive statistics to determine the mean (M), standard deviation and variance. The summary of the results of the descriptive analysis was presented in Table 2.

Table 2. The Recapitulation Result of Mathematical Knowledge Competency

\begin{tabular}{ccc}
\hline Descriptive Statistics & Experimental Group & Control Group \\
\hline N & 34 & 35 \\
Minimum Score & 60 & 56 \\
Maximum Score & 96 & 88 \\
Mean & 81,21 & 72,29 \\
Variance & 89,48 & 80,50 \\
Standard Deviation & 9,45 & 8,97 \\
Mean \% & $81,21 \%$ & $72,29 \%$ \\
\hline
\end{tabular}

Based on Table 2, it can be seen that most of the students' scores in the experimental group tended to be high. To determine the level of competency scores for mathematical knowledge in the experimental group, the five scales of PAP assessment criteria were used. Based on the average percentage, the score of experimental group was obtained 81.21. Whereas in the control group, most of the students scores tended to be low with an average score of 72.29. The following was the classification based on the five scales of PAP post-test data for the two sample groups was presented in Table 3.

Table 3. The Data Classification of Students' Mathematical Competency Post-test

\begin{tabular}{ccc}
\hline Five Scales of PAP & Experimental & Control \\
\hline Very good & 5 students & - \\
Good & 16 students & 7 students \\
Sufficient & 9 students & 20 students \\
Poor & 4 students & 8 students \\
Very Poor & - & - \\
\hline
\end{tabular}

Based on Table 3, it can be seen that post-test score of mathematical knowledge from 16 experimental group students was in good category, while the post-test score of mathematical knowledge from 20 control group students in sufficient category. Based on the percentage average value of the two samples, it can be seen that the average value of the mathematics knowledge competency score of the experimental group taught by the portfolio assessment model based NHT is higher than the average value of the control group's mathematics knowledge competency score.

Before testing the hypothesis, a prerequisite test was firstly conducted which included the normality test and the variance homogeneity test. The normality test was conducted to prove that the frequency of the research data was truly normally distributed. The results of the data distribution normality test obtained the Chi Square count of the post-test results $\left(x^{2}\right.$ count $\left.=5.97\right)$ and $x^{2}$ the table with a significance level of $5 \%$ and $\mathrm{dk} 5$ was 11.07 . It means that the post-test result of the experimental group was smaller than $\mathrm{X}_{\text {table }}\left(x^{2}\right.$ count $<x^{2}$ table) so that the post-test result data of the experimental group was normally distributed. For the control group normality test results, obtained the Chi Square count of the post-test results (count $=7.51$ ) was obtained and $x^{2}$ table with a significance level of $5 \%$ 
and $\mathrm{dk} 5$ was 11.07. It means that the control group's post-test result count is smaller than the table $\left(x^{2}\right.$ count $<x^{2}$ table) so the control group's post-test result data is normally distributed.

The homogeneity test of variance was conducted on the variance of pairs between the experimental group and the control group. The test was the F-test with homogeneous data criteria if $\mathrm{F}_{\text {count }}<\mathrm{F}_{\text {table. }}$ Based on the calculation results of homogeneity test, it was found that the $\mathrm{F}_{\text {count }}$ of competency in mathematical knowledge of the experimental and control groups was 1.11, while the Ftable in the $\mathrm{dk}_{\text {numerator }}=33, \mathrm{dk}_{\text {denominator }}=34$, at the $5 \%$ significance level was 1.78 . It means that the variance of the data on the competency of mathematical knowledge in the experimental group and the control group is homogeneous.

Based on the analysis results of the prerequisite hypothesis test, it was found that the competency data of the experimental group and control group mathematical knowledge was normal and homogeneous so that the t-test of the research hypothesis could be tested. Hypothesis testing was performed using t-test statistics with the polled variance formula. The test criterion was that $\mathrm{H}_{0}$ was rejected if $t_{\text {count }}>t_{\text {table, }}, t_{\text {table }}$ was obtained from the $t$ distribution table at a significanc of $5 \%$ with degrees of freedom $\mathrm{dk}=\mathrm{n}_{1}+\mathrm{n}_{2}-2$. The following can be presented in Table 4 .

Table 4. The Result of T-Test

\begin{tabular}{ccccc}
\hline Group & $\mathbf{N}$ & $\mathbf{D k}$ & $\mathbf{t}_{\text {count }}$ & $\mathbf{t}_{\text {table }}$ \\
\hline Experimental & 34 & 67 & 4,351 & 2,000 \\
Control & 35 & & & \\
\hline
\end{tabular}

The results of the t-test analysis (post-test) obtained $t_{\text {count }}=4.351$ and $t_{\text {table }}=2,000$ for $\mathrm{dk}=67$ at the $5 \%$ significance level. Based on the testing criteria, because $t_{\text {count }}>$ table, the null hypothesis $\left(\mathrm{H}_{0}\right)$ was rejected and $\mathrm{H}_{\mathrm{a}}$ was accepted so it can be stated that there is a significant difference in the competency of mathematical knowledge of the group that was taught using the portfolio assessment based NHT model with the group that was taught conventionally in the fifth grade elementary school Cluster VIII Mengwi Academic Year 2019/2020.

First, through direct observation of NHT model implementation combined with portfolio-based assessment in the experimental group learning, students are enthusiastic and active and do not feel afraid to learn mathematics anymore. It cannot be separated from the application of the NHT model. The NHT model is one of the cooperative learning models in which the chasing process is done in small groups. The NHT model is group learning that involves 3-5 people to solve a problem and the NHT model is chosen because it is suitable to be applied to the learning process because it can involve all students actively, not just one or two people (Atiyah et al., 2019; Fajar Kurniati, 2017). By applying this learning model, it will make students learn more actively and do not just wait for the teacher to deliver the material. Students' activity in learning can be seen from the steps of the NHT model. The syntax of the NHT model is divided into five phases, namely (1) numbering, the teacher divides students into groups of 3-5 people and assigns a different number to each group member; (2) asking questions, the teacher proposes problems or gives student worksheets and this is done with the group; (3) thinking together in groups, students discuss problems given by the teacher; (4) answering a question, the teacher calls a random number to work on the results of the discussion; (5) the conclusion, the teacher and students conclude the learning (Fajar Kurniati, 2017). The enthusiasm and activeness of students during the experimental group learning can be seen in the syntax of the portfolio assessment model based NHT which triggers an increase in the competency of students' knowledge, namely the $2^{\text {nd }}$ and $5^{\text {th }}$ syntax. The second syntax is to ask a question: the teacher explains that worksheets of student's groups work will be used as portfolios and it is put in folders. Then, at the $5^{\text {th }}$ syntax, namely the conclusion: the teacher and students will conclude the learning and provide an assessment of the discussion results that have been discussed. In this step, students will know the acquisition of the group's value so that if the students get wrong, they will be motivated to improve and further increase it so that they can balance the groups as well as get high scores (Kurniasih \& Sani, 2015). By combining the portfolio assessment, the child is motivated in learning. Portfolio assessment is an assessment of selected student work for a certain period of time. The selected work in question is the best, memorable, and meaningful work for students (Sumardi, 2017). In this study, portfolio assessment is manifested in the form of worksheets collection and individual evaluations which are done by students and given a grade. If the results of student assignments are not optimal, they will be given corrections, and the results are collected again and then they are stored properly into the folder. Meanwhile, students with optimal are given motivation to further improve their learning outcomes. This portfolio assessment has a good impact on 
teachers and students, namely being able to find out the development or progress of student learning outcomes. Through portfolio assessments, students can find out material that has not been understood and motivate students by comparing the results of previous work with current jobs, while for teachers, it is used to find out the development of individual students and make it easier for teachers to guide less competent students (Alentina et al., 2013; Hasnawati, 2017).

Second, the use of the NHT model in learning in the experimental group makes students more flexible in expressing their opinions. There are no dominant students in the discussion because the teacher will randomly call the student numbers to answer the results of the discussion on behalf of the group. By giving the same opportunity, students will share their answers and knowledge with each other and can foster students' confidence. It is in line with the benefits of the Numbered Head Together learning model according to (Priansa, 2017), namely students' self-confidence increases, students' communication skills increase, tolerance is more developed, understanding of the material gets deeper, and improves student learning outcomes. In addition, (Berlin \& Kurniasih, 2015) state that the advantages of the NHT model are increasing students' achievement, deeper students' understanding, a higher sense of student responsibility, more developed curiosity, increasing students' self-confidence, more developed a sense of cooperation, and more student motivation in mastering the material. In addition, students are required to always be ready in learning participation and all groups need to understand the given problems because the teacher randomly calls the student's number during the discussion. Student learning readiness can directly affect the learning process. It is supported by the opinion from ( Effendi, 2017) that readiness is physical maturity and growth, intelligence, background experience, standard learning achievement, motivation, perception, and other factors that allow a person to learn. In addition, the existence of a portfolio assessment makes students motivated in learning because students' abilities can be seen from day to day so that it makes students active in learning and increases the competency of mathematical knowledge. In addition, the existence of teacher's portfolio is allowed students to find out the progress of students individually or in groups and motivate students during lessons (Kusuma et al., 2015). Through portfolio assessments, teachers can document and assess student work results so that they can monitor student progress from day to day and encourage students to reflect on their own learning. Thus, students can be motivated and improve their learning outcomes (Darsana et al., 2019).

Third, the NHT model demands cooperation among groups to cover up weaknesses in the group and try to solve problems together (Novitasari, 2016). In addition, the use of this model aims to provide opportunities for students to share ideas and consider the most appropriate answers. The NHT model is part of the structural cooperative learning model, which emphasizes special structures designed to influence student interaction patterns (Sudarwanto, 2018). The interaction among students is very important because the interaction from all directions will create good learning and planned learning outcomes are achieved. (Febriyanti \& Seruni, 2015) state that the interactions in the learning process can influence students' interest, motivation, and learning outcomes.

Furthermore, the implementation of conventional learning in control group is influenced by the following things. Learning is mostly done by delivering material from the teacher. In addition, the teacher also provides exercises with the same questions as explained by the teacher, only with different numbers. It causes the learning atmosphere monotonous so that students are less enthusiastic and active to participate in learning. In conventional learning, students tend to be passive and teachers provide material or knowledge dominantly. Students only tend to accept what the teacher says and it will affect students. Students feel bored and uncomfortable in learning. It is in line with the opinion of (Wungguli \& Yahya, 2020) that conventional learning, in general, tends to only be conveyed by the teacher, it makes students feel bored so students tend to play in learning process. It is also in line with the opinion of (Sobron et al., 2019) which states that the implementation of conventional learning continuously will affect students' motivation.

The results of this study are also supported by several relevant studies to strengthen this research, namely the results of a study conducted by (Riani et al., 2014) which states that the effectiveness of the NHT model with a portfolio is better than the TGT, it is shown by the results of the average value of the NHT experimental group learning outcomes is 28.47. A study conducted by (Astianawan et al., 2016) states that students' mastery of mathematical knowledge competencies is increase using portfolio assessment. (Muliandar's study, 2019) shows that the NHT model affects mathematics learning outcomes. A study conducted by (Wayan et al. (2015) states that student mathematics learning outcomes are increase by implementing scientific expectations based on portfolio assessments. A study conducted by (Setiani et al., 2014) states that the NHT model influences student mathematics learning outcomes. (Sugiyadnya et al., 2019) state that the NHT model affects the competency of students' mathematical knowledge; (Rati \& Sucidamayanti's study, 2017) show that 
student learning outcomes increase from cycle I to cycle II due to the implementation of the NHT model, and (Pangestu \& Kadir's study (2019) states that student learning outcomes increase using the NHT model.

Based on the research findings, the NHT model and portfolio assessments are able to make students ready, active, enthusiastic, and arouse student motivation in learning so that it has an impact on students' mathematical competency. It can be seen from student group discussions, there are no students who dominate the learning because in the implementation of this model all students in their groups must understand the problems given indirectly to train students' readiness and responsibility. Many students are active during the activity, it can be seen from the question and answer activity as well as the collaboration with their groups. Through the collection of each student's work also increases students' motivation because students are always given a grade in every process so that students know their weakness and make their low previous work results as a motivation to get more optimal grades.

In addition, the obtained implications after this treatment are the selection of the NHT model and the portfolio assessment is appropriate and suitable to be applied because the learning objectives can be achieved optimally and mathematics learning becomes directed and structured. This model and assessment influences increasing the competency of students' mathematical knowledge. The results of this study indicate that portfolio assessment based NHT model is good for mathematics learning because it can generate motivation, activeness, readiness, enthusiasm, and students' responsibility. The practical implications of the research result is that it can be used as teaching materials for teachers to choose variations in teaching models.

\section{Conclusion}

Based on result of described study and discussion, it can be concluded that the RME learning model affects the competency of Mathematics knowledge after controlling the Numeric Ability of the fifth-grade elementary school students in Cluster II, North Kuta District Academic Year 2019/2020. Considering the advantages of RME, this model can be used in learning.

\section{References}

Adnyana, I. K. S., Sumantri, M., \& Suwatra, I. W. (2014). Penerapan Model Pembelajaran Numbered Heads Together Untuk Meningkatkan Aktivitas Dan Hasil Belajar IPA Pada Siswa Kelas V SD NO. 7 Kampung Baru Kecamatan Buleleng Tahun Pelajaran 2013/2014. PGSD Universitas Pendidikan Ganesha, 2 (1). http://dx.doi.org/10.23887/jjpgsd.v2i1.3000.

Alentina, N. P., Putra, M., \& Negara, I. G. A. O. (2013). Model Pembelajaran Sinektik Berbasis Penilaian Portfolio Terhadap Hasil Belajar IPS Siswa Kelas V SD Gugus Letkol Wisnu Denpasar Utara. Mimbar PGSD Undiksha, 1 (1). http://dx.doi.org/10.23887/jjpgsd.v1i1.1559.

Astianawan, I. P., Wiarta, I. W., \& Ganing, N. N. (2016). Penerapan Pendekatan saintifik Berbasis Penilaian Portfolio dapat Meningkatkan Kemampuan Pemecahan Masalah dan Penguasaan Kompetensi Pengetahuan Matematika Siswa Kelas II. E-Journal PGSD Universitas Pendidikan Ganesha, 4(1), 1-10. http://dx.doi.org/10.23887/jjpgsd.v4i1.7088.

Atiyah, N., Usodo, B., \& Ekana C, H. (2018). Penerapan Model Pembelajaran Kooperatif Tipe Numbered Head Together (NHT) Dengan Pendekatan Quantum Learning Untuk Meningkatkan Keaktifan Belajar Matematika Siswa Kelas VIG SMP Negeri 1 Ngawen Klaten. 2(4), 307-314. https://doi.org/10.20961/jpmm\%20solusi.v2i4.22758.

Atiyah, U., Fita, M., Untari, A., \& Tsalatsa, A. N. (2019). Keefektifan Model Pembelajaran Numbered Head Together ( NHT ) Dengan Media Teka-Teki Silang Terhadap Hasil Belajar Tematik Siswa. International Journal of Elementari Education, 3(1), 46-52. http://dx.doi.org/10.23887/ijee.v3i1.17284.

Berlin, S., \& Kurniasih, I. (2015). Ragam Pengembangan Model Pembelajaran Untuk Peningkatan Profesionalitas Guru (A. Jay (ed.); I). Kata Pena.

Darsana, I. G. B., Wiarta, I. W., \& Putra, M. (2019). Pengaruh Model Problem Based Learning Berbasis Portfolio Terhadap Kompetensi Pengetahuan Matematika. 3, 200-207. http://dx.doi.org/10.23887/jppp.v3i3.18608.

Djonomiarjo, T. (2020). Pengaruh Model Problem Based Learning Terhadap Hasil Belajar. Aksara: Jurnal Ilmu Pendidikan Nonformal, 5(1), 39. https://doi.org/10.37905/aksara.5.1.39-46.2019 
Dwicahyani, N. M., Wiarta, I. W., \& Ardana, I. K. (2019). Penerapan Model Pembelajaran Nht Berbantuan Media Gambar Meningkatkan Penguasaan Kompetensi Ips. Journal for Lesson and Learning Studies, 2(1), 102-110. https://doi.org/10.23887/jlls.v2i1.17326

Effendi. (2017). Hubungan Readiness ( Kesiapan ) Belajar Siswa Dengan Hasil Belajar Fisika Siswa Kelas X Smk. Jurnal Pendidikan Fisika, 5(1). http://dx.doi.org/10.24127/jpf.v5i1.740.

Fajar Kurniati, S. (2017). Pengaruh Model Pembelajaran Kooperatif Tipe Numbered Heads Together ( Nht ) Dengan Menggunakan Media Visual Terhadap Pengetahuan Konseptual Fisika Siswa Sma. Jurnal Pendidikan Fisika, 65-101. http://jurnal.unimed.ac.id/2012/index.php/jpf/article/download/7642/pdf.

Febriyanti, C., \& Seruni, S. (2015). Peran Minat dan Interaksi Siswa dengan Guru Dalam Meningkatkan Hasil Belajar Matematika. Formatif: Jurnal Ilmiah Pendidikan MIPA, 4(3), 245-254. https://doi.org/10.30998/formatif.v4i3.161

Hadiyanti, R., Suhito, \& Kusni. (2012). Keefektifan Pembelajaran Kooperatif Numbered Head Together Terhadap Kemampuan Pemahaman Konsep. Journal of Mathematict Education, 1(1), 60-65. https://doi.org/https://doi.org/10.15294/ujme.v1i1.262

Hartono, B., Wiarta, I. W., \& Suniasih, N. W. (2015). Penerapan Pendekatan Saintifik Berbasis Asesmen Portfolio Untuk Meningkatkan Hasil Belajar Pengetahuan Matematika Dan Sikap Spiritual Tema Cita-Citaku Siswa Kelas IV SD. PGSD Universitas Pendidikan Ganesha, 3. http://dx.doi.org/10.23887/jjpgsd.v3i1.4948.

Hasnawati. (2017). Model Berbasis Portfolio Untuk Meningkatkan Partisipasi Belajar Siswa Pada Pembelajaran PKN. JPPI, 1(3), 19-26. https://doi.org/http://dx.doi.org/10.29210/02017105

Juniyanti, N. L., Suniasih, N. W., \& Kristiantari, M. G. R. (2015). Model, Numbered Heads Together, aktivitas, hasil belajar. PGSD Universitas Pendidikan Ganesha, 3(12).

Kemendikbud. (2016). Indonesian National Assesment Programme.

Kurniasih, \& Sani. (2015). Ragam Perkembangan Model Pembelajaran Untuk Meningkatkan Profesionalitas Guru. Kata Pena.

Kusuma, P. I., Suniasih, N. W., \& Wiarta, I. W. (2015). Penerapan Pendekatan Saintifik Berbasis Asesmen Portfolio Untuk Meningkatkan Hasil Belajar Pengetahuan Matematika Dan Sikap Sosial Siswa Pada Tema Cita-Citaku Kelas IV SD N 4 Ubung. PGSD Universitas Pendidikan Ganesha, 3. http://dx.doi.org/10.23887/jjpgsd.v3i1.5164.

Mariani. (2017). Penerapan Model Pembelajaran Make A Match Untuk Meningkatkan Hasil Belajar Matematika Tentang Pembagian Pada Siswa Kelas II SD Muhammadiyah 4 Batu. JINoP Jurnal Inovasi Pembelajaran), 3(2), 599. https://doi.org/https://doi.org/10.22219/jinop.v3i2.5306

Marselina, K. T., \& Kristiantari, M. R. (2019). Pengaruh Pendekatan Pembelajaran Matematika Realistik Berbasis Portfolio Terhadap Kompetensi Pengetahuan Matematika. Journal of Education Technology, 3(2), 81-87. https://doi.org/http://dx.doi.org/10.23887/jet.v3i2.21708

Muliandari, V. (2019). Pengaruh Model Pembelajaran Kooperatif Numbered Head Together (Nht) Terhadap Hasil Belajar Matematika Siswa Kelas V Sd. Indiktika: Jurnal Inovasi Pendidikan Matematika, 2(1), 10. https://doi.org/10.31851/indiktika.v2i1.3224

Novitasari, D. (2016). Pengaruh Penggunaan Multimedia Interaktif Terhadap Kemampuan Pemahaman Konsep Matematis Siswa. FIBONACCI: Jurnal Pendidikan Matematika Dan Matematika, 2(2), 8. https://doi.org/10.24853/fbc.2.2.8-18

OECD. (2016). Country Note - Results from PISA 2015: Indonesia. Oecd, 1-8.

OECD. (2018). What 15-year-old students in Indonesia know and can do. Programme for International Student Assessment (PISA) Result from PISA 2018, 1-10.

Oktarini, N. W. S., Putra, I. K. A., Putra, I. M., Guru, P., \& Dasar, S. (2014). Pengaruh Penerapan Model Pembelajaran Kooperatif Denpasar Utara Universitas Pendidikan Ganesha. http://dx.doi.org/10.23887/jjpgsd.v2i1.2488.

Pangestu, C. B., \& Kadir. (2019). Meningkatkan Hasil Belajar Matematika Siswa Melalui Model Pembelajaran Kooperatif Tipe Numbered Head Together (NHT). ALGORITMA Journal of 
$\begin{array}{llll}\text { Mathematics } \quad \text { Education } & \text { (AJME), }\end{array}$

http://journal.uinjkt.ac.id/index.php/algoritma/article/view/11686.

Paramita, D. K., Garminah, N. N., \& Wibawa, I. M. C. (2016). Penerapan Model Pembelajaran Kooperatif Tipe Nht Berbantuan Media Audio Visual Untuk Meningkatkan Hasil Belajar IPA. PGSD Universitas Pendidikan Ganesha, 4, 1-10. http://dx.doi.org/10.23887/jjpgsd.v4i1.6954.

Priansa, D. J. (2017). Pengembangan Strategi \& Model Pembelajaran (I). CV Pustaka Setia.

Putu, N., Wiantari, Y., Putra, M., \& Wiarta, I. W. (2017). Pengaruh Model Pembelajaran Kooperatif Tipe Numbered Head Together Berbantuan Media Audio-Visual Terhadap Kompetensi Gugus Letda Made Putra Universitas Pendidikan Ganesha. http://dx.doi.org/10.23887/jjpgsd.v5i2.10651.

Rati, N. W., \& Sucidamayanti, N. P. W. (2017). Penerapan Model Pembelajaran Kooperatif Tipe Numbered Heads Together Untuk Meningkatkan Hasil Belajar IPS. International Journal of Elementary Education, 2, 115-124. http://dx.doi.org/10.23887/ijee.v1i2.11603.

Riani, F., Adi, I. G., Yasa, S., Sunarya, I. M. G., \& Wahyuni, D. S. (2014). Studi Komparatif Model Pembelajaran Kooperatif Tipe Numbered Heads Together ( NHT) Dan Teams Games Tournament ( TGT ) Berbantuan Asesmen Portfolio Terhadap Hasil Belajar Siswa Pada Mata Pelajaran Teknologi Informasi Dan Komunikasi Kelas VII Smp Laborato. (KARMAPATI), 3(4), 239-242. https://ejournal.undiksha.ac.id/index.php/KP/article/view/19701/11708.

Setiani, K. Y., Tegeh, I. M., \& Japa, I. G. N. (2014). Pengaruh Model Nht Berbasis Penilaian Kinerja Terhadap Hasil Belajar Matematika Ditinjau Dari Kemampuan Numerik Siswa Kelas IV. PGSD Universitas Pendidikan Ganesha, 2. http://dx.doi.org/10.23887/jjpgsd.v2i1.3851.

Sobron, A. ., Bayu, Rani, \& Meidawati. (2019). Persepsi Siswa Dalam Studi Pengaruh Daring Learning Terhadap Minat Belajar IPA. SCAFFOLDING: Jurnal Pendidikan Islam Dan Multikulturalisme, 1(2), 30-38. https://doi.org/10.37680/scaffolding.v1i2.117.

Sudarwanto, W., Relmasira, S. C., \& Juneau, J. L. (2018). Penerapan Model Pembelajaran Kooperatif Tipe NHT Berbantuan Media Simulasi Gambar Untuk Meningkatkan Hasil Belajar Siswa Kelas 4 SD Semester 1 Tahun 2017/2018. 1-10.

Sugiyadnya, I. K. J., Wiarta, I. W., \& Putra, I. K. A. (2019). LOGO Jurnal Pengaruh Model Pembelajaran Kooperatif Learning Tipe NHT terhadap Pengetahuan Matematika. 3(4), 413-422. http://dx.doi.org/10.23887/ijee.v3i4.21314.

Sugiyono. (2015). Metode Penelitian Kuantitatif Kualitatif. Alfabeta.

Sumardi, S. (2017). Pengembangan Model Penilaian Portfolio dalam Pembelajaran Matematika Berbasis $\begin{array}{lllll}\text { Lesson Study di SMP. Jurnal } & \text { VARIDIKA, 28(2), }\end{array}$ https://doi.org/10.23917/varidika.v28i2.3031

Wayan, N., Juliawati, T., Suniasih, N. W., \& Wiarta, I. W. (2015). Untuk Meningkatkan Hasil Belajar Pengetahuan Matematika Dan Pengetahuan Metakognitif Siswa Pada Tema Cita-Citaku. Universitas Pendidikan Ganesha e-Journal PGSD Universitas Pendidikan Ganesha pandangan dasar bahwa suatu pengetahuan tidak dapat dipindahkan $\quad b$. https://ejournal.undiksha.ac.id/index.php/JJPGSD/article/download/5111/3855.

Wungguli, D., \& Yahya, L. (2020). Pengaruh Penggunaan Media Berbasis Information and Communication Technology (ICT) terhadap Hasil Belajar Siswa pada Materi Dimensi Tiga. Jambura Journal of Mathematics Education, 1(1), 41-47. https://doi.org/10.34312/jmathedu.v1i1.5376

Yuliantari, N. P. E., Wiarta, I. W., \& Abadi, I. B. G. S. (2016). Penerapan Model Problem Bas ed Learning Dapat Meningkatkan Keaktifan Dan Penguasaan Kompetensi Pengetahuan Matematika Siswa. PGSD Universitas Pendidikan Ganesha, 4, 1-11. http://dx.doi.org/10.23887/jjpgsd.v4i1.7037. 